\title{
A social innovation for combating discrimination against persons with disabilities in the built environment
}

The rights of persons with disabilities to barrier-free access and equal opportunities are guaranteed by numerous documents at the international and national levels, but various studies and daily experience show that these legal provisions have not always been implemented in practice. Persons with disabilities continue to experience numerous barriers in the urban environment. This situation shows that current approaches to eliminating environmental barriers are inadequate and that there is an urgent need to search for alternative, more effective solutions. This article presents such a novel solution, premised on the hypothesis that significant progress in this area will be achieved only through restructuring the roles of the major stakeholders. The author thus proposes a reversal of roles, suggesting the introduction of a bottom-up approach as opposed to the current ineffective top-down approaches. In order to facilitate such a bottom-up approach, an interactive internet portal has been designed that is presented and described in this article as a "web forum". Based on a thorough review of the literature on the notion of "social innovation", it is argued that the suggested new approach is a social innovation, an attribute that qualifies it as an effective mechanism that will lead to eventually achieving barrier-free environments and consequently eliminating discrimination against persons with disabilities in the living environment.

Key words: persons with disabilities, discrimination, living environment, barrier-free access, bottom-up approach, social innovation 


\section{Introduction}

Disability has been globally recognised as an important political issue, especially in connection with guaranteeing universal human rights. According to the World Health Organization (2011), there are one billion people with physical disabilities in the world. In Europe, it is estimated that functionally impaired people make up 15 to $20 \%$ of the working-age population. This means that one in five to six people of working age (age sixteen to sixty-four) has either a long-standing health problem or a disability. Given the rapidly increasing older population in developed countries, especially those over eighty, the percentage of functionally impaired people might be expected to grow in the future. These relatively large numbers notwithstanding, people with disabilities regrettably often face discrimination and negative attitudes, and experience various forms of barriers that affect their health, wellbeing and quality of life. As such, removing built-environment and communication barriers in order to guarantee full accessibility to persons with disabilities and enable their active participation in society presents a major challenge worldwide.

On the political side of the problem, numerous conventions, declarations, strategies, laws, regulations, technical standards, programmes and guidelines have been adopted, tackling various aspects of discrimination against persons with disabilities. At the international level, these have included the Treaty of Amsterdam adopted by the European Commission in 1997 and the standard regulations for equal opportunities for the disabled adopted by the UN General Assembly in 2006. This was the first legally binding international document concerning disability, with the fundamental aim of guaranteeing realisation of human rights and the principle of equal opportunities and equal treatment, as well as preventing discrimination against the disabled. This important document was ratified by the Slovenian parliament in 2008. The convention recognises the importance of accessibility to the physical, social and economic environment and access to information and communication technologies in enabling people with disabilities to fully use and enjoy human rights and basic freedoms. Another key document in this area is the European Disability Strategy 2010-2020, launched by the European Commission in November 2010, which outlines the principle strategy for achieving the full participation of persons with disabilities in society and the economy.

In addition to ratification of various international documents, the rights of persons with disabilities in Slovenia are guaranteed by the constitution and various laws and regulations. Regrettably, however, research has shown that the ratification of international conventions and adoption of laws have not resulted in their actual implementation in practice. Evidence of the failure to achieve any major improvement in this area may be found in a noticeable increase in recent decades in the number of researchers and other experts focusing on the situation of persons with disabilities in Slovenia. The most important among these include: a comparative analysis of independent living of the disabled in selected European Union countries (Kobal et al., 2004); two studies by Mateja Nagode and Polona Dremelj $(2004,2005)$ focusing on analysis of social support networks for people with mobility impairments and two studies by Barbara Kobal et al. (2006, 2007) investigating issues concerning funding. Barbara Kresal (2007) edited a publication describing in detail the rights of the disabled in Slovenia, and a study by Slavka Kukova et al. (2005) discussed the rights of people with intellectual disabilities. Furthermore, Slovenia was also among the eleven partner countries that participated in an EU-funded research project (LivingAll: Free Movement and Equal Opportunities for All), the results of which showed that in the majority of countries covered by the survey laws are either insufficiently implemented or not implemented at all (Garcés et al., 2007). As such, one of the major recommendations of the research project was developing new methodologies and mechanisms that are more effective in implementing measures to removal barriers in the living environment. Similar conclusions were also reached by the most comprehensive study to date in this area in Slovenia (Sendi et al., 2011). This three-year research project exhaustively investigated the living conditions of persons with disabilities and the major barriers they experience in their daily lives. Its main finding was that they continue to encounter numerous barriers in the built environment that would have been eliminated long ago if the adopted conventions and relevant legal provisions had been fully implemented in practice. These studies have usually produced various recommendations for national authorities, all aiming to introduce measures to guarantee greater success in efforts to create a barrier-free environment.

The urgency of achieving this objective motivated a group of researchers at the Urban Planning Institute of the Republic of Slovenia to search for and develop new solutions that introduce new and more effective approaches to tackling the complex issues at hand. The principle hypothesis in the search for an alternative solution was that current attempts to deal with the problems of inaccessibility in the living environment have failed, primarily because policymakers have not been able to recognise the urgency of actively involving targeted groups in implementing the various programmes intended to eliminate barriers in the living environment. Premised on this hypothesis, the thesis is advanced that significant progress in this area will be achieved only through restructuring and reversing the roles of the major stakeholders. The search for an alternative approach was thus based on the conviction that the road to 
success in this area lies in effectively engaging persons with disabilities to participate in concrete actions to detect and redress all forms of barriers in the living environment. The result of this effort is the web forum, which is presented and described here as a mechanism that has great capacity to facilitate the giant step forward from paper declarations to the actual creation of barrier-free environments. The web forum is a novel bottom-up solution that enables easier and accurate detection of existing built-environment and communication barriers, and at the same time it also serves as a mechanism for constantly monitoring activities in the built environment and, thus, for preventing the occurrence of new barriers. The underlying argument is that previous top-down approaches have not been fully successful in achieving the objectives of numerous international and national documents on barrierfree access. The proposed bottom-up approach is described as a social innovation. The definition of the suggested novel approach as a social innovation is premised on a thorough review of the available literature on the theoretical concept. This theoretical background is used to identify and describe the major characteristics of the proposed bottom-up approach, which qualify it as a social innovation. As defined by Agnès Hubert et al. (2010: 33), social innovations are "new ideas (products, services and models) that simultaneously meet social needs (more effectively than alternatives) and create new social relationships or collaborations."

The remainder of this article first sets up the theoretical background, examining the basic concept of the notion of social innovation and laying out the theoretical framework for later interpolation with the proposed bottom-up approach. It then introduces and describes the purpose and nature of the interactive web forum, which has been developed and is proposed as a more effective alternative solution. Finally, the article utilises the theoretical concept presented to identify the key elements that characterise the proposed novel approach as a social innovation.

\section{Theoretical background to social innovation}

In order to define the web forum as a social innovation, it is first necessary to lay out the theoretical background for identifying the major elements that qualify it to be characterised as such. A review of the literature on social innovation shows that the subject has so far received limited academic discourse. This situation is described by various authors with expressions such as "relatively understudied" (Sharra \& Nyssens, 2009), "under investigated" (Mumford, 2002) and "research in this area is in its infancy" (Read, 2000), whereas Jürgen Howaldt and Michael Schwarz (2010) and Frank Moulaert et al. (2005) recognise a surge in the topic in social science analyses in the western world over the last twenty years. As observed by Eduardo Pol and Simon Ville (2009: 2), "[t]he term 'social innovation' has entered the discourse of social scientists with particular speed, but there is no consensus regarding its relevance or specific meaning in the social sciences and humanities." Some authors (e.g., Robert Grimm et al., 2013) have expressed concern that the concept has been stretched in so many directions, almost to the "breaking point". The intensification of discourse on the subject may be construed as a recognition of its topicality by some social scientists (e.g., Martin, 2006; Cajaiba-Santana, 2014), who have premised their discussion on the subject on the conviction that social innovation has a crucial role to play in efforts to achieve institutional change to better living conditions. The various challenges of modern society call for exploiting alternative innovative approaches that are more effective in dealing with social changes that continually impact the wellbeing and living conditions of groups and particular individuals (Lehtola \& Ståhle, 2014). The intricacies of applying the concept of social innovation, especially in urban development, have been discussed in an extensive publication by Paul Drewe et al. (2008) presenting a compilation of various case studies, focusing mainly on urban revitalisation.

Tracing back its origins, some writers on the subject (e.g., Mouelaert et al., 2005; Mumford, 2002; Howaldt \& Schwarz, 2010; Hubert, 2010) refer to the earlier introduction of the social innovation theme by Max Weber at the end of the nineteenth century and Joseph Schumpeter in the 1930s. The lack of adequate attention to this subject has also been noticed by Geoff Mulgan et al. (2006: 5), who have written that "surprisingly little is known about social innovation compared to the vast amount of research into innovation in business and science". This scholarly literature deficit has been further recognised by the authors of the report of the Workshop on Social Innovation, which was produced under the auspices of the Bureau of European Policy Advisers (BEPA) of the European Commission, who found that the subject was "insufficiently researched" (Hubert et al., 2010). In view of the absence of extensive academic debate on the topic, it is generally accepted that there is no established definition of social innovation in the current literature (Pol \& Ville, 2009). Anthony Read (2000) finds an initial difficulty in innovation research in defining exactly what innovation is. He makes reference to other researchers (Abramson, 1991; Eveland, 1991, cited in Wolfe, 1994) that have expressed the belief that a general theory of innovation is impossible due to the many complexities involved. Such is also the view of Michael D. Mumford (2002), who suggests that methodological complexity is one of the major considerations that has made it difficult to study and define social innovation.

Despite this relative under-theorisation of the subject, various authors have identified several characteristics and suggested 
various definitions of social innovation that provide a useful context within which to discuss and draw support to characterise the web forum that has been designed as a social innovation. Starting with a simple, clear-cut definition, Frances Westley and Nino Antadze (2010: 15) have defined social innovation as "those processes, products, and initiatives that profoundly challenge the system that created the problem that they seek to address". Social innovation, they argue, introduces changes that fundamentally alter basic routines of the social system in which the innovation occurs. This brief definition appropriately summarises the line of thinking shared with other authors that have discussed the subject. One such author is Mumford (2002), who has identified several similar characteristics of social innovation, including the following:

- "Social innovation refers to the generation and implementation of new ideas about how people should organise personal activities, or social interaction, to meet one or more common goals" (ibid: 253);

- "Social innovation might involve the creation of new processes and procedures for structuring collaborative work, the introduction of new social practices in a group, or the development of new business practices" (ibid: 253);

- "Social innovation requires ideas and solutions that are based on identifying a limited number of manageable key issues" (ibid: 263);

- "Social innovation is, at its core, an inherently practical activity in which benefit must be demonstrated in a relatively short period" (ibid: 264);

- "Social innovation involves a willingness to rearrange or restructure existing social relationships to address the issue at hand" (ibid: 264).

The statements quoted above may be condensed to highlight the major characteristics of social innovation, according to Mumford (2002), as addressing issues at hand, the implementation of new ideas, social interaction, the creation of new processes and restructuring social relations.

Similarly, Moulaert et al. (2005: 1970) have contributed to the discussion, maintaining that "the general social rationale of social initiatives is to promote inclusion into different spheres of society (especially the labour market, education system and social-cultural life)." They define the following dimensions of social innovation (ibid: 1976):

- "satisfaction of human needs that are not currently satisfied, either because 'not yet' or because 'no longer' perceived as important by either the market or the state (content/product dimension);

- "changes in social relations, especially with regard to governance, that enable the above satisfaction, but also increase the level of participation of all but especially deprived groups of society (process dimension);
- "increasing the socio-political capability and access to resources needed to enhance rights to satisfaction of human needs and participation (empowerment dimension)."

For the purposes of their article, Moulaert et al. (2005: 1978) then formulate the following four-statement working definition of social innovation:

- "Social innovation is path-dependent and contextual. It refers to those changes in agendas, agency and institutions that lead to a better inclusion of excluded groups and individuals in various spheres of society at various spatial scales.

- "Social innovation is very strongly a matter of process innovation - i.e. changes in the dynamics of social relations, including power relations.

- "As social innovation is very much about social inclusion, it is also about countering or overcoming conservative forces that are eager to strengthen or preserve social exclusion situations.

- "Social innovation therefore explicitly refers to an ethical position of social justice. The latter is of course subject to a variety of interpretations and will in practice often be the outcome of social construction."

For Moulaert et al. (2005) social innovation is therefore about changing agendas in order to include excluded groups, satisfying human needs, changing social and power relations, overcoming conservative forces that preserve social exclusion practices, participation of deprived groups and empowerment.

In one of the rare specialised journals on the subject (the Stanford Social Innovation Review), James A. Phills et al. (2008: 34) define social innovation as "the process of inventing, securing support for and implementing novel solutions to a social problem." More precisely, they define social innovation as "a novel solution to a social problem that is more effective, efficient, sustainable, or just than existing solutions and for which the value created accrues primarily to society as a whole rather than private individuals" (ibid: 34 ). In this case, social innovation is seen as a process that commences with inventing a solution to solve a social problem for the good of society in general. In a similar manner, Robin Murray et al. (2010: 3) define social innovation as "new ideas (products, services and models) that simultaneously meet social needs and create new social relationships or collaborations. In other words, they are innovations that are both good for society and enhance society's capacity to act." In addition to delivering good for society, this definition also refers to the creation of new social relations and the enhancement of society's role. Similar views are also referenced by Howaldt and Schwarz (2010: 23), who have quoted Alexander Kesselring and Michaela Leitner's (2008) definition, which states that social innovations are elements of 
social change that "create new social facts, namely impacting the behaviour of individual people or certain social groups in a recognizable way with an orientation towards recognized objects that are not economically motivated." Kesselring and Leitner's definition thus adds a new and vital element to the definitions mentioned above; namely, the non-economic motivation of a social innovation. In the same vein, Pol and Ville (2009) explain that social innovations are not driven by the profit motive as is the case with business innovations, which are essentially profit-seeking new ideas created with the intention of making money.

The work performed by the researchers that participated in the BEPA Workshop on Social Innovation is certainly one of the most detailed studies to date on the subject of social innovation (Hubert et al., 2010). Their extensive report provides a thorough description of the key issues of social innovation, on the basis of which they develop their own definition of the notion. Among others things, they specify the following major characteristic elements:

- "The overriding social issue for the longer term is how to equip individuals with the right skills to give them the best chance in the modern economy as workers, entrepreneurs and consumers" (ibid: 21).

- "Social innovation also mobilises each citizen to become an active part of the innovation process" (ibid: 30 ).

- "Innovation refers to the capacity to create and implement novel ideas which are proven to deliver value. 'Social' refers to the kind of value that innovation is expected to deliver: a value that is less concerned with profit and more with issues such as quality of life, solidarity and well-being ... As it is used now in public and scientific debates, it is about developing innovative solutions and new forms of organisation and interactions to tackle social issues" (ibid: 33 ).

- "In general, social innovation can be defined as a new response to pressing social demands, which affect the process of social interactions. It is aimed at improving human well-being" (ibid: 33).

- "Social innovations are innovations that are social in both their ends and their means. Specifically, we define social innovations as new ideas (products, services and models) that simultaneously meet the social needs (more effectively than alternatives) and create new social relationships or collaborations. In other words, they are innovations that are not only good for society but also enhance society's capacity to act" (ibid: 33 ).

The authors recognise that "social innovation, as a new and emerging concept, cannot be encapsulated within a tight definition with strictly designated actors, objectives and means" (Hubert et al., 2010: 42). On the basis of this recognition, they develop a definition composed of two dimensions:

a. The process dimension, which defines social innovation as "relating to the development of new forms of organisation and interactions to respond to social issues" (ibid: 43); and

b. The outcome dimension, which suggests that social innovation aims at addressing:

- "Social demands that are traditionally not addressed by the market or existing institutions and are directed towards vulnerable groups in society.

- "Societal challenges in which the boundary between 'social' and 'economic' blurs, and which are directed towards society as a whole.

- "The need to reform society in the direction of a more participative arena where empowerment and learning are sources and outcomes of well-being" (ibid: 43).

The key elements of social innovation specified in the BEPA study are therefore equipping individuals, mobilising citizens, creating and implementing novel ideas, responding to pressing social demands, creating new social relationships, addressing vulnerable groups and enhancing society's capacity to act to the benefit of society as a whole. Whereas the process and outcome dimensions suggested in the definition formulated by the authors of the study essentially make reference to characteristics similar to those already presented above, they also introduce two vital elements: participation and empowerment. Both elements are crucial for ensuring success in implementing new solutions. The active involvement of the general public has the capacity for effectively transforming critical societal problems into viable solutions (Lisetchi \& Brancu, 2014).

For still better legibility, Figure 1 uses keywords to summarise the reviewed definitions of social innovation, following Mumford (2002), Moulaert et al. (2005) and Hubert et al. (2010). Figure 1 reveals a wide variety of expressions used to describe the notion of social innovation, according to three of the authors included in the literature review presented above. However, from Figure 1 it is possible to discern several elements that are common to the thinking of these authors and the other authors reviewed. This makes it possible to further condense the summarised keywords in order to identify four basic characteristic elements of social innovation. These are:

- Initiation;

- Creation of new ideas;

- Mobilisation of citizens;

- Achieving change.

The final section of this article utilises these basic elements to define the proposed bottom-up approach as a social innovation. 
Characteristics of social innovation

Mumford (2002)

- Addressing issues at hand

- Generating and implementing new ideas

- Organising personal activities

- Social interaction

- Creating new processes

- Structuring collaborative work

- Introducing new social practices

- Rearranging or restructuring existing social relationships
Moulaert et al. (2005)

- Promoting inclusion

- Giving a voice to marginalised groups

- Governance

- Capacity building

- Satisfying human needs

- Changes in social relations

- Changes in agendas

- Including excluded groups

- Increasing socio-political capability

- Participation

- Empowerment

- Social inclusion

- Overcoming conservative forces that preserve social exclusion situations

- Social justice
Hubert at al. (2010)

- Equipping individuals with the right skills

- Mobilising citizens

- Creating and implementing novel ideas

- Responding to pressing social demands

- Improving human wellbeing

- Creating new social relationships and collaborations

- Enhancing society's capacity to act

- Social interaction between individuals

Figure 1: Characteristic elements of social innovation according to various authors.

\section{The web forum: A bottom-up approach}

To put it simply, the proposed bottom-up approach is designed to operate as a web forum. The web forum is essentially an interactive internet portal that was created to enable the active participation of persons with disabilities, as well as the general public, in identifying and redressing all types of builtenvironment and communication barriers, in any place over the entire territory of Slovenia. The web forum is basically a medium for gathering information on all forms of barriers that are experienced by persons with disabilities in their daily lives. It exploits the possibility of using social media "as a platform to effectively support the processes of social innovation, overcoming its limitations of speed and scale to become an alternative to currently established institutional mechanisms" (Hans-Werner et al., 2012: 13). As such, it offers an easy and effective means of gathering information on accessibility with the help of the general public. The web forum facilitates the strategic use of the internet, helping to disseminate timely and relevant information (Yousef \& Vilkomerson, 2014). Public participation in spatial planning (which must strive to ensure a barrier-free built-environment) with the help of web tools has been described as a mechanism that constitutes part of the democratic process and considerably reduces the possibility of negative influences (Bizjak, 2012). People are invited to provide information about any barriers that they observe in their living environment. Enabling persons with disabilities themselves to identify the concrete barriers they encounter is the first stage and one of the most important elements of the proposed new approach. It is suggested and argued that one of the reasons for the lack of progress in eliminating barriers is the failure of current approaches to include mechanisms for systematically identifying existing barriers. Notwithstanding the current abundance of laws and regulations concerning barrier-free access, there is presently no system in place to monitor their strict implementation in practice. The national authorities (specifically, the building inspectorate), who have the legal authority to act in this respect, have not been found to be very active in detecting regulatory violations and imposing the prescribed sanctions. The underlying argument here is that the ineffectiveness of the building inspectorate presents one of the weakest points of the current top-down approaches. The suggested bottom-up approach thus offers a simple and quite effective solution to this problem. Persons with disabilities are the ones that have the most accurate knowledge of the barriers that prohibit them from fully participating in the living environment. Enabling them to actively participate in identifying these barriers is the first major step in the series of actions that need to be performed to achieve any significant improvement in this area. It is also vital to point out that, in addition to identifying existing barriers, the general public is also requested to report "barriers in creation" - that is, those that they observe being newly constructed. The purpose of this action is, of course, to prevent the occurrence of new barriers. The proposed bottom-up approach, which is centred on mobilising the general public to assume an active role in the fight against built-environment and communication barriers, is a novel alternative that will certainly lead to the eventual elimination of various forms of urban environment discrimination. Aidan Cerar (2012) has described such involvement of the general public as reactive participation, which is characterised by greater motivation to act in order to achieve improvement, 


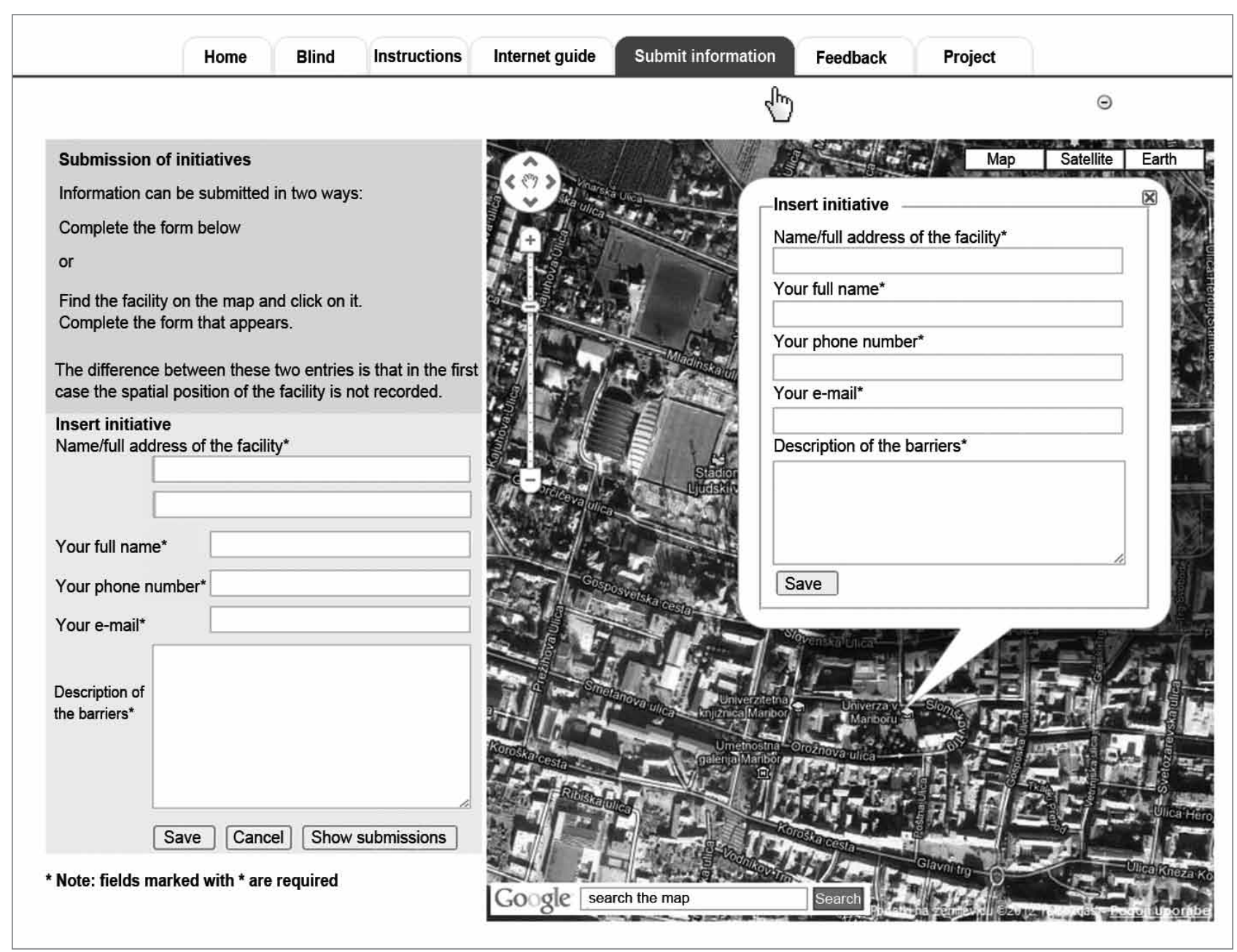

Figure 2: Submitting information on the web forum.

as opposed to the type of contributive participation that Igor Bizjak (2012) describes.

The system designed provides two ways of supplying information on the web forum. First, this may be done by entering the required information directly into the window that appears when the user clicks on "submit information" (Figure 2).

The second option is to click on a particular facility on the map, whereby a window opens into which the relevant information is entered. In either case, the participant is required to supply the following information: name of place, name/type of facility, address of facility, postal code, e-mail address of participant and a brief description of the nature of the barrier being reported. The only difference between the two methods is that the designers of the forum recognised that some participants may not wish to scroll through Google Maps to locate the particular facility they want to report. In addition to reporting barriers, the web forum also provides persons with disabilities with a medium for the mutual exchange of information and experiences. As such, it is also intended to serve as a communication social network through which people with disabilities will be encouraged to develop new ideas and forward further proposals for improvement. It is also important to point out that a special menu was created that enables access to and participation of the blind and partially sighted in all web forum activities.

As already stated, the information gathered on the web forum is only the first step in the process of eliminating barriers. Someone then has to receive and act on the information gathered. This, of course, requires setting up an appropriate and effective system for handling and processing the material obtained. This is to be done by the monitoring service, which is effectively the executive part of the web forum. The monitoring service is responsible for operating and following the proceedings on the web forum and performing the initial processing of the information obtained. The initial processing stage involves sorting the information into the following four main actions:

- Respond to an inquiry or provide requested information on issues concerning accessibility;

- Alert the owner/manager of the particular facility about the reported barrier(s); 


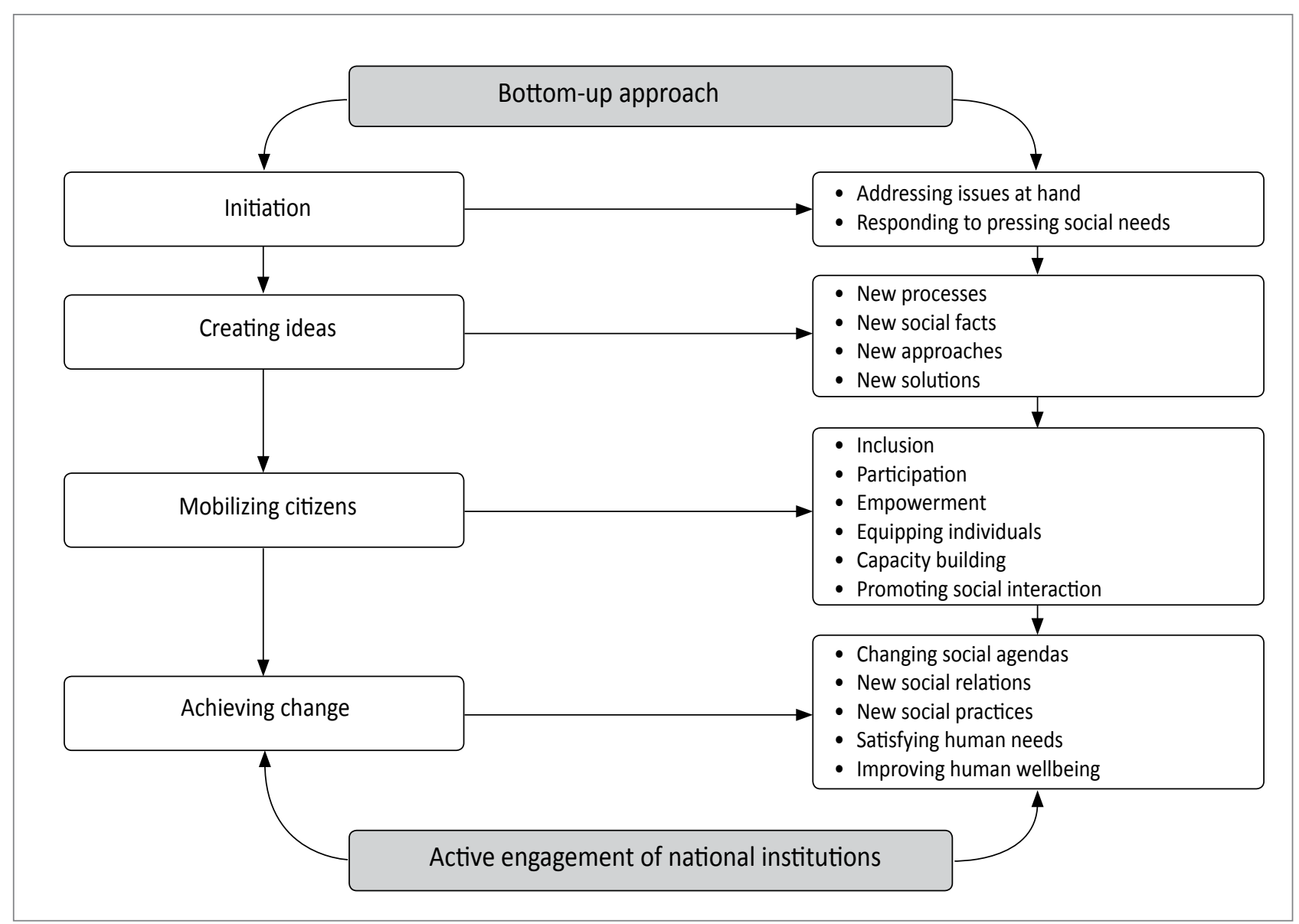

Figure 3: Social innovation chain.

- Take urgent action (notify the responsible national control authority, especially in the case of new construction underway that blatantly violates current barrier-free regulations);

- Conduct further field investigations if there is a need to verify the exact nature of the reported barrier.

The information sorted in this way is then passed on to the responsible institutions or experts, who are required to take appropriate action, as recommended by the monitoring service. As stressed in the conclusion, this bottom-up approach must be supported by active and dedicated involvement of the responsible national institutions, especially by applying appropriate sanctions for violations. It is also vital that the web forum presents another novel solution: it significantly simplifies the building inspectorate's work, thus potentially increasing its effectiveness in prosecuting violations and ensuring full compliance with the prescribed standards.

To sum up, the proposed bottom-up approach is intended to serve two major purposes. First, it provides a very effective mechanism for identifying barriers, both existing ones and those in the making, and reporting them for appropriate action. Second, it significantly simplifies the process of de- tecting barriers, facilitating the work of the national institutions responsible for ensuring barrier-free access. As such, the bottom-up approach is designed as a driver with the capacity to coerce responsible national institutions to assume a more active role in implementing policies and actions intended to eliminate barriers in the living environment. This is the essence of the reversal of roles that is characteristic of the proposed bottom-up approach.

The following section utilises the theoretical concept advanced from the literature review to suggest and provide proof that the proposed bottom-up approach has all the major characteristics that clearly qualify it as a social innovation.

\section{Defining the bottom-up approach as a social innovation}

To clearly identify the basic elements of the proposed novel approach that characterise it as a social innovation, the article builds on the theoretical framework presented above to design a social innovation chain. This theoretical concept is utilised to incorporate into it the key elements of the proposed novel approach, to help establish its characteristics as a social innova- 
tion. The social innovation chain relationships are schematically illustrated in Figure 3.

As Figure 3 shows, social innovation is a process that is executed through a sequence of events. This process is referred to as the social innovation chain. The designation "bottom-up approach" is purposely placed at the top of the Figure in order to emphasise the reversal of roles. As such, "active engagement of national institutions" is placed at the bottom, where it is envisaged as the final stage of the chain. The social innovation chain thus initiates with the recognition of the presence of a social problem that needs to be addressed. In this case, the development of the web forum was initiated by the findings of the two research projects referred to in the introduction (the European-wide EU-funded LivingAll project and the more focused Slovenian research). The initiation of the innovation was thus triggered by the continued existence of a social problem. In other words, the process of designing the web forum was initiated in response to a pressing social need. The two research projects that investigated the situation of persons with disabilities provided the background knowledge that supplied the impetus to proceed to the next step of the social innovation chain: the search for new ideas.

This approach to the search for new ideas was guided by the recognition that "the more grassroots, spontaneous, creative initiatives, those which develop against or seek to change established practices from below, are also the most innovative" (Moulaert et al., 2005: 1972). It was therefore imperative to focus the search for new ideas on the social groups affected by the issues being addressed; that is, on those that would most benefit from the proposed solution. Concretely, this meant proposing alternative solutions that enable the active involvement of persons with disabilities in the performance of activities intended for removing barriers in the living environment. The importance of the participation of concerned groups in carrying out new ideas was stressed by Hubert et al. (2010: 35) in the statement that "[s]olutions must focus on the beneficiaries and be created with them, preferably by them, and never without them." This requirement ties in appropriately with the next stage of the social innovation chain.

The mobilisation of citizens is the stage during which the participation of citizens in implementing new ideas and solutions is facilitated. The web forum provides an effective medium for mobilising citizens. It is vital to stress that the medium is not intended solely for the use of persons with disabilities. Everyone is invited to actively participate in identifying existing barriers and preventing the occurrence of new ones. Everybody (persons with disabilities and others) have the opportunity to contribute information on existing barriers and are also encouraged to forward complaints through the forum concern- ing all forms of urban environment discrimination. As has been established by the literature review, the mobilisation of citizens is a measure that is essential for developing new forms of social relations and promoting social interaction. Hubert et al. (2010) also maintain that innovations that are implemented through the inclusion, participation and empowerment of citizens are not only good for society but also enhance society's capacity to act. In this regard, the web forum is also expected to make a major contribution to raising general awareness about the situation of persons with disabilities and, hopefully, to eliminating all forms of barriers that prevent them from fully participating in society.

The literature review has also indicated that social innovation processes that prioritise citizen participation and promote social interaction are likely to lead to solutions that are more effective and more sustainable. Social interactions between various stakeholders are therefore vital for ensuring the realisation of the determined objectives; that is, achieving change for the better. The web forum offers a perfect medium for facilitating citizen participation and social interaction that is expected to lead to success and achieving change. Achieving change has been described in the literature as encompassing the following: changing social agendas, restructuring existing relationships, creating new social relations, creating new collaborations and new practices, satisfying human needs and improving human wellbeing. The web forum advances the current political (lip service) rhetoric on eliminating discrimination against persons with disabilities to a higher level, where the removal of builtenvironment and communication barriers becomes a more realisable goal than in the past. In short, the web forum is an innovation that is not only good for society but also enhances society's capacity to act to improve human wellbeing.

In summary, the proposed bottom-up solution suitably incorporates the specified major stages of the social innovation chain. As such, it manifests all the basic characteristic elements required to define it as a social innovation.

\section{Conclusion}

The bottom-up approach described above is the mechanism that enables the giant leap from declarations on paper to effective concrete action. The interactive web forum presents a comprehensive mechanism that, to our knowledge, is the first of its kind among current approaches to tackling builtenvironment and communication barriers. The proposed novel solution clearly has the capacity to achieve considerable success in an area where current approaches have failed to bring about the desired improvements. The next major challenge is, of course, the successful implementation of the social in- 
novation. Mumford (2002: 263) has rightly cautioned: "Not only does social innovation apparently call for some unique skills and expertise, it also makes some unique demands with regard to solution implementation." It is important to stress here that the implementation of the web forum also requires the active engagement of national institutions (ministries, government bodies, various public organisations) responsible for care for persons with disabilities. Their dedicated involvement is crucial for successfully implementing the bottom-up approach. Proposing this novel approach in no way minimises the important role that must be played by national institutions in order to bring about positive change. The actions of the responsible national institutions constitute the final stage of the bottom-up approach. The new approach requires that national institutions and the various bodies responsible for ensuring compliance with relevant planning and building regulations effectively carry out their respective tasks. The role of the building inspectorate in particular in imposing sanctions for violations is paramount. This is also the point of entry of the legislature and all national bodies with relevant legislative powers. To this effect, it is strongly recommended that more stringent punitive measures be introduced, which must also be more rigorously enforced in the case of failure to comply with the legal requirements concerning barrier-free access. Successfully implementing the new approach thus greatly depends on the anticipated complementary role of the responsible national institutions, which is foreseen as the final link in the social innovation chain. Implementing the new approach would, of course, require some national budget expenditure to cover the costs for the enhanced level of engagement of the inspectorate services. However, this is the minimum cost that has to be borne by the state in order to guarantee persons with disabilities full inclusion in society. In fact, it may be argued that the state pays a much higher price by failing to guarantee a level of accessibility that offers persons with disabilities better opportunities to fully participate in all spheres of life and the economy in order to improve their own wellbeing. As such, the proposed bottom-up approach may also be expected, in the long run, to contribute to reducing national financing for caring for persons with disabilities. If all actors effectively carry out their tasks, in the near future there may be significant improvements that will result in eventually eliminating discrimination against persons with disabilities in the living environment and facilitating their full and effective participation and inclusion as equal citizens in society. Finally, this proposed novel approach has the capacity for transfer to other countries - subject, of course, to country-specific adjustments.

Richard Sendi

Urban Planning Institute of the Republic of Slovenia, Ljubljana,

Slovenia

E-mail: richard.sendi@uirs.si

\section{Acknowledgment}

The author expresses his gratitude to the Slovenian Research Agency and the Ministry of Labour, Family and Social Affairs, which co-funded the research project that this article is based on. He is also greatly indebted for the commitment and efforts invested by the researchers that participated in developing and designing the web forum. Special thanks also go to the Disabled Students Association of Slovenia, especially its individual members, who participated in the field research.

\section{References}

Bizjak, I. (2012) Improving public participation in spatial planning with Web 2.0 tools. Urbani izziv, 23(1), pp. 112-124.

DOI: 10.5379/urbani-izziv-en-2012-23-01-004

Cajaiba-Santana, G. (2014) Social innovation: Moving the field forward. A conceptual framework. Technological Forecasting and Social Change, 82, pp. 42-51. DOI: 10.1016/j.techfore.2013.05.008

Cerar, A. (2014) From reaction to initiative: Potentials of contributive participation. Urbani izziv, 25(1), pp. 93-106. DOI: 10.5379/urbani-izziv-en-2014-25-01-002

Drewe, P., Klein, J. L. \& Hulsbergen, E. (eds.) (2008) The challenge of social innovation in urban revitalization. Amsterdam, Techne Press.

Fisk, M. J. (2001) The implication of smart home technologies. In: Peace, M. S. \& Holland, C. (eds.) Inclusive housing in an ageing society. Innovative approaches, pp. 101-124. Bristol, Policy Press.

Franz, H. W., Hochgerner, J. \& Howaldt, J. (2012) Challenge social innovation: Potentials for business, social entrepreneurship, welfare and civil society. Heidelberg, Springer-Verlag. DOI: 10.1007/978-3-642-32879-4_1

Garcés, J., Sendi, R., Černič Mali, B., Kerbler, B. \& Kobal Tomc, B. (2007) Free movement and equal opportunities for all (LivingAll). Compilation and classification of the national policies and action plans in Europe (LivingAll national initiatives report). Valencia, Polibienestar.

Grimm, R., Fox, C., Baines, B. \& Albertson, K. (2013) Social innovation, an answer to contemporary societal challenges? Locating the concept in theory and practice. Innovation: The European Journal of Social Sciences, 26(4), pp. 436-455. 10.1080/13511610.2013.848163

Howaldt, J. \& Schwarz, M. (2010) Social innovation: Concepts, research fields and international trends. Dortmund, Sozialforschungsstelle Dortmund \& ZWE der TU-Dortmund.

Hubert, A. (2010) Empowering people, driving change: Social innovation in the European Union. Brussels, European Commission.

Kesselring, A. \& Leitner, M. (2008) Soziale Innovationen in Unternehmen. Vienna, Unruhe Stiftung.

Kobal, B. Dremelj, P. \& Nagode, M. (2007) Analiza socialno ekonomskega položaja invalidov za pripravo Zakona o izenačevanju možnosti invalidov. Ljubljana, Social Protection Institute of the Republic of Slovenia.

Kobal, B., Dremelj, P., Nagode, M. \& Smolej, S. (2006) Analiza transferjev za invalide. Ljubljana, Social Protection Institute of the Republic of Slovenia.

Kobal, B., Tjaša, Ž. \& Smole, S. (2004) Neodvisno življenje invalidov $v$ izbranih državah evropske unije. Ljubljana, Social Protection Institute of the Republic of Slovenia.

Kresal, B. (ed.) (2007) Vodnik po pravicah invalidov v slovenski zakonodaji. Ljubljana, Institute for Labour Law at the Faculty of Law. 
Kukova, S., Zaviršek, D. \& Urh, Š. (2005) Rights of people with intellectual disabilities. Access to education and employment: Slovenia (monitoring report). Budapest, Open Society Institute.

Lehtola, V. V. \& Ståhle, P. (2014) Societal innovation at the interface of the state and civil society. Innovation: The European Journal of Social Sciences, 27(1), pp. 152-174. DOI: 10.1080/13511610.2014.863995

Lisetchi, M. \& Brancu, L. (2014) The entrepreneurship concept as a subject of social innovation. Procedia - Social and Behavioural Sciences, 124, pp. 87-92. DOI: 10.1016/j.sbspro.2014.02.463

Martin, B. (2006) Social testing. Social Alternatives, 25(4), pp. 39-42.

Moulaert, F., Martinelli, F., Swyngedouw, E. \& Gonzalez, S. (2005) Towards alternative model(s) of local innovation. Urban Studies, 42(11), pp. 1969-1990. DOI: 10.1080/00420980500279893

Mulgan, G., Tucker, S., Ali, R. \& Sanders, B. (2006) Social innovation: What it is, why it matters, how it can be accelerated. London, Basingstoke Press.

Mumford, M. D. (2002) Social innovation: Ten cases from Benjamin Franklin. Creativity Research Journal, 14(2), pp. 253-266. DOI: 10.1207/S15326934CRJ1402_11

Murray, R., Caulier-Grice, J. \& Mulgan G. (2010) The open book of social innovation. London, Young Foundation and Nesta.

Nagode, M. \& Dremelj, P. (2004) Omrežja socialne opore oseb z gibalnimi težavami. In: Novak, M. (ed.) Omrežja socialne opore prebivalstva Slovenije, pp. 121-129. Ljubljana, Social Protection Institute of the Republic of Slovenia.

Nagode, M. \& Dremelj, P. (2005) Spolne razlike v omrežjih socialne opore za ljudi z gibalnimi težavami s Sloveniji. Socialno delo, 44(1-2), pp. 117-123.

Phills. J. A., Deigmeir, K. \& Miller, D. T. (2008) Rediscovering social innovation. Stanford Social Innovation Review, 6(4), pp. 34-43.

Pol, E. \& Ville, S. (2009) Social innovation: Buzz word or enduring term? The Journal of Socio-Economics, 38(6), pp. 878-885.

DOI: 10.1016/j.socec.2009.02.011

Read, A. (2000) Determinants of successful organisational innovation: A review of current research. Journal of Management Practice, 3(1), pp. 95-119.

Sendi, R., Kerbler, B., Bizjak, I, Goršič, N., Tominc, B., Mujkić, S. et al. (2011) Ukrepi za uresničevanje pravic invalidov do dostopa brez ovir: inventarizacija obstoječih ovir v grajenem okolju in v objektih v javni rabi po Sloveniji: končno poročilo. Final report. Ljubljana, Urban Planning Institute of the Republic of Slovenia.

Sharra, R. \& Nyssens M. (2009) Social innovation: An interdisciplinary and critical review of the concept. Louvain-la-Neuve, Université Catholique de Louvain.

Westley, F. \& Antadze, N. (2010) Strategies for scaling social innovation for greater impact. The Innovation Journal: The Public Sector Innovation Journal, 15(2), pp. 2-18.

Wolfe, R. A. (1994) Organisational innovation: Review, critique and suggested research directions. Journal of Management Studies, 31(3), pp. 405-431. DOI: 10.1111/j.1467-6486.1994.tb00624.x

Yousef, T. J. \& Vilkomerson, R. (2014) Public policy in divided societies: The role of policy institutes in advancing marginalized groups. Innovation: The European Journal of Social Sciences, 27(1), pp. 46-66.

DOI: 10.1080/13511610.2013.777274 